\title{
Rabbani Education: Basic Concepts, Design and Implications of Rabbani Education Learning
}

\author{
Nurul Anam ${ }^{1}$, Moh. Rofid Fikroni², \\ ${ }^{1}$ Institut Agama Islam Al Qadiri Jember, ${ }^{2}$ Institut Agama Islam Negeri Jember \\ Inurul.anam86@gmail.com, ${ }^{2}$ rofidfiks@gmail.com
}

\begin{abstract}
Rabbani education is a basic concept to overcome various problems in human life. This concept is understood as a process that actively develops human potentials through the process of purification, instilling and incarnation into a generation of rabbani. From this understanding, there are three core processes of rabbani education, namely the process of purification, instilling, and incarnation. The design of rabbani education learning is centered within AlQur'an Surah Al-Alaq verses 1-5. This surah is the first revelation revealed to the Prophet Muhammad. Not only this revelation signifies that the prophet as an Apostle or messenger, but also as a student who was educated by God and became an educator for all humanity. This first revelation contains the core theory of learning design. Therefore, the basic concept and design of rabbani education learning has several implications that can be actualized in the context of Islamic education in this century, namely: 1) rabbani education empties and ends at the peak of a life mission, which is divinity or monotheism; and 2) rabbani education that had been through by the Prophet Muhammad is a reflection of the ideality of an Islamic education process.
\end{abstract}

Keywords: Rabbani Education, Basic Concept, Design, Learning Implication

\section{Introduction}

Various multidimensional crises seem to keep afflicting people in the world. People's behavior today is almost resembles something that had been done by the jahiliyah community in the past, even it is considered to be worse than the jahiliyah community themselves. During that time, there were many inhumane behaviors such as adultery, murder, the application of the law of the jungle and so on. Geographically, the Arabian Peninsula is dominated by vast deserts, and possess a hot and dry climate. Nearly five-sixth of the area consists of deserts and rock mountains. ${ }^{1}$ Because of its geographical location, the jahiliyah people like to fight. Men are dominant over women, so sometimes they kill many girls because they are considered to be disgraceful and shameful. ${ }^{2}$ In addition, they also worship idols. Their offerings are centered at the Kaaba, although they

${ }^{1}$ Fadil, SJ., Pasang Surut Peradaban Islam dalam Lintas Sejarah, (Malang: UIN Malang Press, 2008), h. 43-44.

2 Imam Fu'adi, Sejarah Peradaban Islam, (Yogyakarta, Teras, 2011), h. 2.

Tribakti: Jurnal Pemikiran Keislaman

Volume 31, Nomor 1, Januari 2020 
do the same in other places too. They made those idols as a place to ask questions and discern their good fortune and bad luck. Such situation was found within the Arab nations and peninsula before the rise of Islam. ${ }^{3}$

From this reality, the Prophet Muhammad was sent to improve his people. The first revelation received by the prophet was read. An initial act that frees humanity from the non existence of knowledge. Reading and understanding are the door to the development of knowledge. By reading they can understand the series of letters. Arab nations are good at memorizing while memorizing is one of the tools to develop knowledge, therefore the Prophet Muhammad still privileged the memory of Arabic people. The Prophet also made a tradition of recording and writing. ${ }^{4}$ According to Imam Fu'adi, ${ }^{5}$ the prophet was sent to nurture a generation that was able to change the pattern of jahiliyah people to be a civilized or civil society, a tolerant society, one who loves science and good at respecting others and so on.

Whereas at present time, all aspects of human life are experiencing a crisis both in the legal, social, economic, political, cultural and religious aspects. One factor that causes such problems is westernization. Westernization is adapting the Western lifestyle, imitating, and taking over the Western way of life. ${ }^{6}$ Copying the lifestyle means overly imitating Western clothing styles by following the fast changing fashions; mimic the manner of speech and customs of their social courtesy and are often coupled with an attitude of degrading national language and customs; mimicking social patterns, partying patterns (celebrating birthdays), recreational patterns, and drinking habits; etc. ${ }^{7}$

In addition, Abdul Munir Mulkhan ${ }^{8}$ explained that there are many problems and challenges that must be faced in this century. Starting from: 1) Huntington's (1995) perspective on the phenomenon of religious enthusiasm, it turns out that some are just the opposite, suspected of potentially triggering more violent and global conflicts; 2) Berger's (1982) perspective on technology becomes the legitimacy of "colonialism" which views itself as more civilized, making it almost impossible for world welfare to be enjoyed by

\footnotetext{
${ }^{3}$ Badri Yatim, Sejarah Peradaban Islam, (Jakarta: PT RajaGrafindo Persada, 2011), h. 14-15.

4 Musyrifah Sunanto, Sejarah Islam Klasik Perkembangan Ilmu Pengetahuan Islam, (Jakarta: Prenada Media,2004), h.14-15

${ }^{5}$ Imam Fu'adi, Sejarah Peradaban Islam..., h. Iii.

${ }^{6}$ Faisal Ismail, Paradigma Kebudayaan Islam: Studi Kritis dan Refleksi Historis (Yogyakarta: Titian Ilahi Press, 1998), h. 198.

${ }^{7}$ Faisal Ismail, Paradigma Kebudayaan Islam, h. 199.

${ }^{8}$ Abdul Munir Mulkhan, Nalar Spiritual Pendidikan: Solusi Problem Filosofis Pendidikan Islam, (Yogyakarta: PT Tiara Wacana Yogya, 2002), h. 27-33. 
all regions (Scumacer, Small, 1985); 3) Naisbitt's (1994) and Aburdene's (1990) perspective on the information age mega culture and the free market of free trade, still leaves injustice in poverty; 4) Paul Kennedy's perspective (1995) explains the cheating of modern civilization with injustice due to technological malpractice; and 5) Berger's (1982) perspective on history is the story of human "suffering", and finally the message of the prophetic treatise's message fails to be well preserved by history.

To overcome this problem, it seems that it is very unlikely to expect the prophet to be re-assigned to the world. One way that can be done is to bring back the spirit and teachings of Nabawiyah in the context of Islamic education, because this aspect has a very central role to overcome these problems. Islamic education that has the spirit and teachings of Nabawiyah is education that is able to combine physical potential, intellectual intelligence (IQ: Intelligence Quotien, EQ: Emotional Quotien, and SQ: Spiritual Quotien) and intelligence of the heart ${ }^{9}$ ( $\mathrm{u}^{\prime} \mathrm{ad}$ : rational heart or IQ of the heart, dzauq: intuition, qalb: heart, shadr: the creativity of the heart or the EQ of the heart, bashirah: the carefulness of the eyes of the heart or the SQ of the heart, and lubb: the sharpness of the core of the heart) which in the end is centered on one control namely Ladunni Quotient (LQ: Ladunni Intelligence) or intelligence sourced from Nur Ilahiyyah (Surah An-Nur: 35). Such a process in which it had happened during the time of the Prophet Muhammad where God as the Most Educator and the prophet as students, then the prophet became an educator to convey the knowledge he obtained to all mankind. The author termed such Islamic Education process with Rabbani Education which will be discussed in this paper.

\section{Method}

This study used a qualitative research method by using library research. The sources of the data are primary and secondary data. The data were collected by using documentation. Moreover, the data was analyzed by using descriptive method, content analysis, and deductive-inductive. The validation of the data is using triangulation.

${ }^{9}$ Ilung S. Enha, LQ: Eleven Pillars of Intelligence, (Yogyakarta: Kaukaba Dipantara, 2013), h.3-11. 


\section{Discussion}

\section{The Basic Concept of Rabbani Education}

According to Ibn Katsir ${ }^{10}$ in the an-Nihayah fi Gahribil-Hadith, he said, "ArRabbani comes from the word rabb, with the addition of alif and nun behind him as a form of mubalaghah (the level of excessiveness)". Al-Rāghib al-Ashfahani added, al-Rab was etymologically al-tarbiyyah (education). In Arabic it is said rabbahu, rabbāhu, and rabbabahu. The word $a l-R a b$ is a mashdar to show the perpetrators. Whereas the word $a l-r a b b \bar{a} \bar{\imath}$ is related to al-Rab, namely Allah Ta'ala who is the mashdar (the source) and He is the one giving knowledge "(Abu Abdussalam, 2012: 2). ${ }^{11}$ According to Tobroni ${ }^{12}$, the word $r a b b$ is coupled with the word al-amin or al-nas, which implies that Allah, the All-Educating, which are creating, possessing, loving, caring, growing, directing, guiding and completing the needs of humans and nature in an evolutionary manner (gradually) so that it reaches perfection.

Whereas in terms, Imam Al-Ghazali, ${ }^{13}$ believes that rabbani is a person who is close to Allah. The most rabbani servants are the servants who are closest to Allah. This understanding is clarified by Masitha Achmad Syukri, a rabbani servant is a servant who has a special characteristic or characteristics of Rabbani, which is a generation that exemplifies the character of Allah SWT. as Rabb in all their daily thoughts, inclinations, and behavior. Thus, education must be directed to form a generation that will always be imitating the compassionate nature of Allah Rabbul Jalalah who is full of affection and caring for all beings. Of course, this generation is the generation of rabbani. By imitating the nature and compassion of Rabb, they will always pay attention and look at small things to large ones, so they can avoid the act of making damage on earth. In the end, the generation of rabbani is ready to be called as the caliph of Allah Subhanahu wata'ala on earth. $^{14}$

According to Salmān al-`Audah, he stated that the character of rabbāniyah has 10 properties, namely: knowledge, ittibā’ (follower), ikhlās (purely the purpose of his devotion), morality and being civilized, associating well with others, having pride in science, wisdom, knowing the degree of wisdom, doing good deeds, and studying. 'Abd

\footnotetext{
${ }^{10}$ Majdi Al-Hilali, Menjadi Hamba Rabbani, Artikel Halaqah Keluarga 2012, h. 1.

${ }^{11}$ Abu Abdussalam, Konsep Pendidikan Rabbaniyah, Artikel Majelis Penulis, h. 2.

12 Tobroni, Pendidikan Islam: Paradigma Teologis, Filosofis, dan Spiritualitas, Malang: UMM Press, 2008), h. 16.

${ }^{13}$ Majdi Al-Hilali, Menjadi Hamba Rabbani..., h. 1.

${ }^{14}$ Masitha Achmad Syukri, Urgensi Generasi Rabbani, Artikel dalam Majalah al-Haromain, 2013, h. 1-3.
} 
al-'Azīz Kuhail elaborates further on the relationship between the rabbāniyah character and the way it was formed in one comprehensive guide. According to him rabbannī is a Muslim who has an intelligent mind, a living heart and productive limbs, where with his complete personality he is able to assume the responsibility of the Khilafah and being tough in dealing with various situations of change and reform. ${ }^{15}$

From all the explanations above, Muslims can be called as rabbani generation if they have several characteristics:

1. Utilizing and being grateful for all the physical gifts gifted from the mother's womb (Surah An-Nahl: 78);

2. Thinking about the creation of heaven and earth (Surah Ali Imran: 191);

3. Being critical in receiving knowledge or listening to the conversation of others, having the ability to weigh the words, theories, propositions and / or propositions put forward by others (QS. Al-Zumar: 18); ${ }^{16}$

4. Becoming a caliph and carry out the mandate (Surah Al-Baqarah: 30 and Al-Ahzab: 72);

5. Having a willingness to share their knowledge with others, having the responsibility to improve the community and being called as the pioneers of creating prosperity in society (QS. Ibrahim: 2 and al-Ra'd: 19-22);17

6. Remembering Allah to always be close to Him in any condition whether standing, sitting or lying (QS. Ali Imran: 191);

7. Being lucky if his heart is purified by faith, always remember ( $f u a d$ ) to Allah and establish prayer (Surah As-Shams: 9 and Al-A'la: 14-15)

8. Being at peace in his heart when he remembers Allah (Surah Ar-Ra'd: 28)

9. Receiving knowledge directly from the side of Allah (Surah Al-Kahf: 65)

10. Getting the guidance of God's light (QS. An Nur 35).

The above characteristics, item 1 is related to physical potential, item 2-3 is related to IQ, item 4-5 is related to EQ, item 6 is related to SQ, item 7-8 is related to heart intelligence, and item 9-10 is closely related to LQ. $\mathrm{LQ}^{18}$ is centered on the atmosphere

\footnotetext{
${ }^{15}$ Abu Abdussalam, Konsep Pendidikan Rabbaniyah..., h. 2.

16 Jalaluddin Rahmat, Islam Alternatif Ceramah-ceramah di Kampus, (bandung: Mizan, 1986), h. 213-215.

${ }^{17}$ Rahmat.

18 The term LQ proposed by Ilung S. Enha has similarities with the term Transcedental Intelligence / Quotien (TQ) in the perspective of KH. Toto Tasmara. According to KH. Toto Tasmara spiritual intelligence (TQ) provides many opportunities for humans to do, it's just that their freedom must be accompanied by a sense of love that resemble to a sense of responsibility by placing mahabbah lillah (love for God) as the highest truth. They are free to contemplate, dive as far as they are able to satisfy their curiosity, but they must still reappear to their nature as a divine person. TQ is different from SQ. From the scientific aspect, spiritual intelligence that is in the god spot is a physical nature inherent in humans, then spiritual intelligence is a content that is in it, namely testimony and recognition of divinity. See Toto Tribakti: Jurnal Pemikiran Keislaman
} Volume 31, Nomor 1, Januari 2020 
of spirit energy (totality of intelligence) ${ }^{19}$ and becomes the center of control of physical potential, intellectual intelligence and heart intelligence. LQ will appear when all the potential is always oriented to Allah SWT. According to Toto Tasmara, ${ }^{20} \mathrm{IQ}, \mathrm{EQ}$, and SQ will not be able to answer the questions of modern humans who are thirsty in looking for the meaning of life, but the intelligence that is centered on the soul (TQ / LQ) will be able to answer it, because such intelligence directs and guides humans to Divine truth. So, IQ, EQ, and SQ must comply with TQ / LQ.

In other words, LQ carries the mission of combining these three potentials, then the mission itself to give birth to a generation of rabbani who get Nur Ilahiyyah directly. Through the Nur Ilahiyyah itself, the three potentials can be developed with the permission of Allah and the blessing of Allah who directed the generation of rabbani on a straight and happy path in the world and the hereafter. In addition, with Nur Ilahiyyah, humans will have Divine knowledge / ladunni through both wahby ${ }^{21}$ and kasybi ${ }^{22}$ knowledge.

All the characteristics of the rabbani generation above are reflected in the Prophet Muhammad. The Prophet is a messenger who is always close to God and imitates all of His qualities and morals. The Prophet reached the highest quality and considered to be the best creature (QS. Al-Ahzab: 21), because there is the best educational process between Allah as the Most Educator and the Prophet Muhammad as a student, then the Prophet becomes an educator to convey the sciences or verses from Allah to humans.

Tasmara, Kecerdasan Ruhaniah (Transcedental Intelligence): Membentuk Kperibadian yang Bertanggung Jawab, Profesional, dan Berakhlak, (Jakarta: Gema Insani Press, 2001), h. x-xi.

${ }^{19}$ According to Ilung S. Enha, IQ, EQ, and SQ intelligence will not be able to reveal the truth as a whole and be as bright as possible. Therefore, it takes a logic that is broader and deeper than that, namely Laduni intelligence (LQ), because Laduni logic is the embodiment of spiritual intelligence which is the culmination of the accumulation of rational logic, intuitive logic, and spiritual logic. Thus, LQ carries the mission of combining the intelligence of the brain and the intelligence of the heart, to then be connected to the center of the spirit energy atmosphere, because to function LQ requires enormous energy. While the energy that counsels in the heart, is still insufficient. Moreover, just the energy contained in the human brain. Ilung S. Enha, Laduni Quotient: Model Kecerdasan Masa Depan, (Yogyakarta: Kaukaba Dipantara, 2013), h.xi.

${ }^{20}$ See Toto Tasmara, Kecerdasan Ruhaniah (Transcedental Intelligence)..., h. xi.

${ }^{21}$ Ilmu wahby adalah ilmu yang diperoleh tanpa ada proses belajar. Ilmu wahby dibagi menjadi dua macam, yaitu ilmu syariat dan ilmu makrifat. Lihat Rizem Aizid, Aktivasi Ilmu Laduni, (Jogjakarta: Diva Pers, 2013), h. 28.

22 Kasby knowledge is knowledge gained through the learning process. This knowledge is the knowledge of Allah which is given to all His creatures through the way of Kasb (effort), such as the results of reading, writing, listening, researching, thinking, schooling and so forth. See Rizem Aizid, Aktivasi Ilmu Laduni..., h. 32. 
This educational process must be seen as the best example and in this particular case, the author recognize it as Rabbani Education. Rabbani education is a process that actively develops human potential through the process of purification, instilling and incarnation into a generation of rabbani. In this sense, there are three core educational processes: first, the purification process. The purpose of purification is the process of forming humans to become people who always believe and devote to God Almighty. This process was carried out since the human being in the womb, Allah said: "..." Am I not your Lord? "They replied:" That's right (You are our Lord), We are witnesses "..." (Surat Al-A'raf; 172).

This verse is also understood that Allah has educated (introduced) the Prophet Muhammad, Peace be Upon Him and all mankind that Himself as God must be believed, worshiped and loved. The witness process has various indications:

1. This testimony is a symbol of the formation of holiness since before birth

2. This testimony is the beginning of the education process of God and His servant (His spirit). Allah teaches His servants about tauhid which is very basic and foremost.

3. This testimony is an example of laduni science application. In a sacred state, God immediately gives knowledge to his servant. Therefore, all of his servants have the potential to gain laduni knowledge again when he has come out of his mother's womb.

At birth, the prophet preserved his holiness by always believing and devoted so that his heart was always pure / calm (QS. Ar-Ra'd: 28) so that the intelligence of his heart could develop, obtaining wahby knowledge, and die in a state of holiness / calm (QS. Al -Fajr: 27-30).

Secondly, the instilling process. This process is an attempt done by the prophet to always load his body / physique with any good things, then maintaining it and using it properly. In addition, the prophet loads himself with various kind of knowledge both from the books of Allah and human intellectual, ${ }^{23}$ or from the verses of qauliyah and kauniyah, or from the religious and general knowledge (science and technology). This particular effort that was always done by prophet finally made him as a servant who attained the

${ }^{23}$ If people want to become a generation of rabbani, then they must not only learn knowledge that comes from human reason, but also must be sourced from the books / revelations of Allah SWT. According to Imam Al-Ghazali, not all the essence of truth can be achieved through reason, because there is a nature which is an area that cannot be reached by reason. This area is the Rabbani region and cannot be reached except for people who belong to the Rabbani generation. See Lihat Syamsul Kurniawan\&Erwin Mahrus, Jejak Pemikiran Tokoh Pendidikan Islam, (Yogyakarta: Ar-Ruzz Media, 2011), h. 91.

Tribakti: Jurnal Pemikiran Keislaman

Volume 31, Nomor 1, Januari 2020 
degree of knowledge of al-yaqin ${ }^{24}$ (Surah Al-Kautsar: 5) and ainu al-yaqin ${ }^{25}$ (Surah AlKautsar: 7) and gained the knowledge of kasby. In the hadith, the Prophet said:

"The act of learning is required for every Muslim." (HR. Bukhari).

"Whoever wants good in the world, then (do it) with knowledge. Whoever wants good in the hereafter then (do it) with knowledge. Whoever wants both, then (do it) with knowledge" (Narrated by Bukhari and Muslim).

These hadiths show that the prophet does look for any kind of knowledge by himself and he also direct his people to be obliged in pursuing general knowledge and religion. Without having sufficient religious knowledge, humans will experience a crisis of existence as 'abdullah. Likewise, if humans do not understand any general science, then humans will experience a crisis of existence as the caliph fi al-ardl.

Both of the educational processes (purification and instilling) above are done by the Prophet in an istiqamah, balanced and synergistic manner, because the prophet, essentially, is also a human being who on the one hand is a perfect being (QS. At-Tin: 4), but on the other hand is known as a weak human being (QS. An-Nisa: 28), and in the Arabic proverb, it is known that "man is the place for wrong doing and forget". The perfect side of human can be seen when he always tries to conquer and rule the world with all its potential and knowledge. In these efforts, sometimes, humans slip and fall onto a false path. At a time when humans are like that, humans should go back to God and doing the act of repent to return for being holy. The Prophet said: "Every Bani Adam must have done wrong doing, and the best among those people are the ones who repent" (HR Tirmidhi, Ibn Majah, \& Al-Hakim).

Prophet Muhammad as a human being or a model student did not escape being wrong and forgetting. When the prophet makes a mistake and forgets, the prophet directly begs Allah for forgiveness, even though Allah has guaranteed that his sins have been forgiven. Even the prophet is the servant who has the most forgiveness at all times. The Prophet said: "O all people. Repent (seek forgiveness) to Allah because I always repent to Him 100 times a day. (HR. Muslim).

Thirdly, incarnation. The prophet always carried out the process of purification and instilling in istiqamah, balanced and synergistic manner in which it then makes him

\footnotetext{
24 Ilmu Yakin merupakan tingkatan Ilmu yang mengenal Tuhan dengan Ilmu. Abdul Munir Mulkhan, Nalar Spiritual Pendidikan..., h. 353.

${ }^{25}$ Ainul Yakin is a level of knowledge that knows God in addition to knowledge also through the senses. Abdul Munir Mulkhan, Nalar Spiritual Pendidikan..., h. 353.
} 
automatically transformed into the figure of the best and exemplary generation of rabbani for his people. In this case, the prophet has reached the degree of haqqu al-yaqin (Qs. AlWaqi'ah: 95), develops the potential of LQ through getting wahby and kasybi knowledge well, and then becomes ulul albab ${ }^{26}$ (Surah Ali Imran: 190-191 ). The symbol of the generation of rabbani attached to the Prophet Muhammad when he is designated as Rasulullah (Messenger of Allah) at the age of 40 years old. This title was obtained when the prophet do the act of khalwat in the Cave of Hira '.

\section{The Design of Rabbani Education}

The design of rabbani education learning is centered in the Al-Qur'an Surah AlAlaq verses 1-5, Allah says:

"(1) Read, in the name of your Lord who created; (2) He created man from a clot of blood; (3) Read, and your Lord is most gracious; (4) One who teaches (human) by the using instrument in the form of qalam (stationery); (5) He teaches man what he does not know."

This surah is the first revelation revealed to the Prophet Muhammad. This revelation not only signifies that the prophet as an Apostle or messenger, but also as a student who was educated by God and became an educator for all humanity. So, this revelation contains the core theory of learning design.

${ }^{26}$ Those who always maintain their commitment to God, pious by observing obedience (worship), and avoiding acts that are not liked by God. Ahmad Arifi, Politics of Islamic Education: Tracing the Ideology and Actualization of Islamic Education in the Middle of Globalization. (Yogyakarta: Terrace, 2010), p. 120-121. Ulul albab is a term for people who have a mind and use it properly. His intellect is used to think, understand the verses of Allah, both verses that are qauliyah, namely the holy verses of the Koran with messages of values and teachings that are a condition of moral content, and verses of God that are kauniyah, namely all events what happens in the world according to Sunnatullah such as day and night changes, the rotation of the planet and the sun, and other issues that are i'tibar (lessons) for mankind, especially people who want to use their minds. From the many verses about ulul albab, we can identify the characteristics and criteria of ulul albab:

a.They with their intellect realize their existence as human servants of Allah, who have limitations and weaknesses (Q. Ali Imran, 3: 7). 3: 190).

b.Those who intellectually want to take lessons from all natural events in this world (Q.S. Ali Imran,

c. Those who intellectually accept the laws of God with all their heart and realize that every incident, the provisions of God must be true and contain wisdom in it (QS al-Baqarah, 2: 179, 269; Ali Imran, 3: 1, 190 ; al-Ra'd, 13: 19).

d.They with the awareness of their intellectuality maintain the values of morality, do not act that damages their faith, trust Allah with actions that are cruel and dirty (not good and inappropriate) (QS alBaqarah, 2: 197; al-Maidah, 5: 100).

e. Those who always maintain their commitment to God, are pious by observing obedience (worship), and avoiding acts that are not favored by Allah (Q. Ali Imran, 3: 197). AM. Saefuddin, Desekularisasi Pemikiran Landasan Islamisasi, (Bandung: Mizan, 1987), 34.

Tribakti: Jurnal Pemikiran Keislaman

Volume 31, Nomor 1, Januari 2020 
In the first revelation, there are at least two forms of learning design identified: first, learning interaction design. Implicitly, in the surah, there was an interaction between God as the Most Educator and the Prophet Muhammad as His best student. The term Iqra' (read; derived from the word qara'a: reading) means that the Supreme Educator wants his students to actively read (the word qara'a means also to learn, understand, analyze, explore, contemplate, convey, examine and so forth). This interaction is called student oriented / centered interaction (student oriented/centered). The term 'allama (teaching) means that the Supreme Educator will teach his students. Such interactions are called teacher oriented / centered interactions (teacher oriented/centered). Thus, that a good learning process is a process that is sometimes student-centered and sometimes teachercentered according to the situation and the needs of the learning process itself.

In addition, the term khalaqa shows one of the competencies of the Supreme Educator possessed by Allah SWT. The competence of the Supreme Educator is summarized in Asmaul Husna or 99 traits attached to His Essence. With these competencies, God can educate the prophet as the best student, then the prophet incarnates as an educator for all humans.

The Prophet as an educator also has several competencies. These competencies are summarized in the obligatory qualities for the prophet, namely shidiq (honest), amanah (trusted), tabligh (conveying) and fathanah (intelligent). When they are contextualized in accordance with Law No. 14 of 2005 concerning teachers and lecturers, these four characteristics have the same orientation relevance as the four competencies of an educator as mandated in the law, namely pedagogical, personality, social and professional competencies:

1. The nature of shidiq has relevance to personality competence. The term shidiq is a symbol of an educator's personality. By being honest, the Prophet Muhammad was accepted by all circles, even in a Nabawiyah sirah, the prophet was the only people who were honest at that time even though the prophet was not yet an apostle or messenger of Allah.

2. The nature of being trusted has relevance to social competence. If a human being is trustworthy, then he will be easily trusted and respected by other humans. For instance, when the Prophet Muhammad got the title Al-Amin. At that time, the Prophet was young for being 20 years old, but he was asked be a leader in uniting the tribes who were fighting to put Hajar Aswad in the Ka'ba building.

3. The nature of tabligh is relevant with pedagogical competence. In delivering God's messages, the prophet delivered them using various methods, such as lecture, question 
and answer, discussion, assignment, demonstration, experimentation, group work, story methods, proverbs, habituation, example, targhib and tarhib. In addition, the prophet is also able to understand the characteristics, conditions and treat the people or their students well, so that the words of the prophet are always awaited and listened solemnly.

4. The nature of fathanah is relevant with professional competence. An educator must be smart and clever in mastering the material that will be delivered to students and smart in managing the time to always take a rest in carrying out their duties as educators. Prophet Muhammad as a very intelligent and istiqamah. Only once the verses of the Qur'an are conveyed, the prophet are able to memorize it easily and conveyed it to his people, then the prophet did the act of istiqamah in front of his people beforehand.

Toto Tasmara explained that there are several indicators of the characteristics of the prophet, namely: 1) shidiq, the indicators are honest with oneself, towards others, towards God, and spread greetings; 2) mandate, the indicator is the attitude in which he always wants to display an attitude that can be trusted (credible) and respect; 3) tabligh, the indicator is communication skill, strong in facing of pressure, cooperation and harmony; and 4) fathanah, the indicators are wisdom and knowledge, disciplined and proactive, and being able to choose the best for himself or others. ${ }^{27}$

Secondly, the learning curriculum design. The 1-5 verses in the Surah Al-'Alaq summarized some elements in which it can considered to be curriculum elements in the perspective of Law No. 20 of $2003^{28}$ concerning the national education system, namely:

1. Purpose. The second verse of the Surah Al-Alaq shows that Allah created man from a clot of blood, then transformed into a lump of flesh in the form of human. Within humans themselves, there is physical potential, intellectual intelligence and heart intelligence. So, learning objectives must be directed to develop these potentials.

2. Contents. The content or subject matter is listed in the terms khalaqa (created) and malam ya'lam (what he doesn't know). Any of Allah's creations in the form of qauliyah and kauniyah verses must be recited by the Prophet Muhammad and his people. Until now, in general all of God's creations from these verses have become two integrated disciplines, namely general science and religion.

3. Learning materials / tools (media). The term Al-Qalam (pen) is a symbol of learning media. To simplify the learning process, the teacher must use learning media. Allah in educating (conveying revelations) the Prophet Muhammad also used the media namely

${ }^{27}$ Toto Tasmara, Kecerdasan Ruhaniah (Transcedental Intelligence)..., h. 189-239.

28 The curriculum is a set of plans and arrangements regarding the objectives, content and learning materials as well as the methods used to guide the implementation of learning activities to achieve certain educational goals. The Secretary of State of the Republic of Indonesia, Undang-Undang Republik Indonesia No. 20 Tahun 2003 Tentang Sistem Pendidikan Nasional (Sisdiknas), (Bandung: Citra Umbara, 2010), h. 1. Tribakti: Jurnal Pemikiran Keislaman Volume 31, Nomor 1, Januari 2020 
Angel Gabriel (in the medium of human / creature learning also includes forms of media). If it is not through the angel Gabriel, the prophet might have difficulty accepting God's revelation, because the prophet had to ascend first to heaven as in the story of Isra'-Mi'raj.

4. Ways. The method used by Allah in the learning process with the Prophet Muhammad is using two approaches, namely: 1) Student Active Learning (SAL) approach, which is an approach that allows students to play an active role in the learning process so that the learning strategies used are active learning. This approach can be understood from the word iqra '. Example of the method is discussion, question and answer, deliberation and demonstration; and 2) the Teaching Active Learning (TAL) approach, which is the active learning instructor that places the teacher in an active role in the learning process, so that the learning strategies used are passive learning. This term can be understood from the word 'allama. An example of this method is lecture.

The method used by God in evaluating prophets is with qualitative and quantitative evaluations. The examples of qualitative evaluations such as identifying good-bad, right-wrong and halal-haram. One of the applicative example is in surah Abasa verses 1-10 which contains a rebuke (direct evaluation) of God for his treatment of a visually impaired friend, Abdullah Ibn Maktum. ${ }^{29}$ While the example of quantitative evaluation is when Muslims, including prophets, do give charity, then in which it will mathematically to be multiplied to 700 times (QS. Al-Baqarah: 261), and so on.

\section{The Implication of Rabbani Education}

As explained above, rabbani education is an active process of developing human potential through the process of purification, instilling and incarnation into a generation of rabbani. The educational process that places God as the Most Educator and the Prophet

${ }^{29}$ One time the Messenger of Allah was facing the authorities of Quraysh, inviting them to want to accept Islam, at that moment a blind man (Abdullah bin Ummi-Maktum) came groping. Hearing the Apostle stop the conversation, Abdullah ventured to beg the Apostle to teach several verses of the Koran.

Rasul seemed to be disturbed by the presence of Ibn Ummi Maktum and seemed to ignore his request while surly. Then after finishing his meeting with the Quraisy dignitaries, a direct rebuke came from God.

He (Muhammad) was surly and turned away, because a blind man had come to him. Do you know maybe he wants to cleanse himself (from sin), or he (wants) to get the teaching, then the teaching will benefit him? As for those who feel themselves to be sufficient, then you serve it. Even though there is nothing (reproach) to you if he does not clean himself (believe). And as for someone who comes to you immediately (to get teachings), he is afraid of (God), then you ignore him. (Qur'an, verses 1-10)

The prophet then realized his mistake, then he immediately met Abdullah bin Ummi-Maktum and allowed his request earlier. This incident made a great impression on the Messenger of Allah, whenever he met with Abdullah bin Ummi-Maktum, the face of the prophet was always beaming, sometimes he said, "O people who have been the cause of a collection of verses coming down from heaven to me". Hayaatis Shahabah and Abdurrahman Ra'fat Basya were quoted by Ario Antoko, Abdullah bin Ummi-Maktum Muadzin Rasullulah. Taken pada tanggal 4 Mei 2015 dalam http://catatanr10.blogspot.com/2012/04/abdullah-bin-ummi-maktum-muadzin.html. 
Muhammad as students, then the prophet becomes an educator to convey the sciences or verses from Allah to humans.

From the above concept, there are at least a number of implications that can be actualized in the context of Islamic education in this era: first, rabbani education empties and ends at the peak of life's mission, which is divinity or monotheism. Second, the rabbani education which had been through by the Prophet Muhammad is a reflection of the ideality of an Islamic education process. The concept and application of Islamic education must refer to what was done by the Prophet Muhammad. The process of education of the prophet does not tend to one particular ideology and learning theory. Thus, rabbani education reflected in the education of the prophet which does not depend on one ideology, whether conservative, liberal or critical. Rabbani education does not tend to be behavioristic, cognitive, constructivistic, socio-cultural (co-constructiveistic), humanistic, multiple intelligence, or other learning theories. Rabbani education is like the "light" that radiates to the whole concept of education. At the time of the prophet, the terms in the educational ideology and learning theory were not found, but in essence the educational process carried out by the prophet involve the concepts and applications carried out by these learning ideologies and theories.

Therefore, if the basic concept and design of rabbani education learning process can be applied in the current process of Islamic education, this will be the best model for the future of Islamic education, because it can give birth to a generation that can overcome multidimensional crises and bring the nation into baldatun thoyyibatun wa rabbun ghafur (Surah Saba ': 16). From the early time of Islam until now, only the Prophet Muhammad which can be seen as the ideal figure of the rabbani generation. After that, there were many other Islamic figures, even though they were not as ideal as prophets, such as khulafaur rasyidin, the generation that emerged in the golden age of Islam, namely Ibn Sina, Al-Farabi and so on. Wallahu a'lam b as-shawab

\section{Conclusion}

Rabbani education is a process that actively develops human potential through the process of purification, instilling and incarnation into a generation of rabbani. In this sense, there are three core educational processes: first, the purification process. The purpose of purification is the process of forming humans to become people who always believe and devote to God Almighty. This process was carried out since the human being in the womb, Allah said: "... Am I not your Lord?" They answered: "Right (You are our Tribakti: Jurnal Pemikiran Keislaman Volume 31, Nomor 1, Januari 2020 
Lord), We are witnesses" ... "(Surah Al-A'raf 172) Second, the process of filling in or instilling. This process is an attempt by the prophet to always fill his physical / body with good things, then maintain and use it well, besides, the prophet instills himself with various good knowledge from the books of God as well as human reason, or from verses qauliyah or kauniyah, or from the religious and general knowledge (science and technology). The effort that is always done by the prophet finally makes himself as a servant who reaches the degree of science al-yaqin (QS Al-Kautsar: 5) and ainu al-yaqin ${ }^{30}$ (Surah Al-Kautsar: 7) and receive knowledge of Kasby. Third, incarnation. When the prophet always carried out the process of purification and instilling in istiqamah, balanced and synergistic manner, the prophet automatically incarnated to be the figure of a generation of rabbani who are the best example and has become the role model for his people. In this case, the prophet has reached the degree of haqqu al-yaqin (Qs. AlWaqi'ah: 95), who develops the potential of LQ through getting wahby and kasybi knowledge well, and becomes ulul albab (Surah Ali Imran: 190-191 ). The symbol of the generation of rabbani attached to the Prophet Muhammad is when the prophet is designated as Rasulullah (Messenger of Allah) at the age of 40 years. This title was obtained when the prophet doing the act of khalwat in the Cave of Hira'.

The design of rabbani education learning process is centered in the Qur'an AlAlaq verses 1-5, Allah Said: "(1) Read in the name of your Lord who created. (2) He created man from a clot of blood. (3) Read, and your Lord is most gracious. (4) The one who teaches (man) by the delivery of the qalam (stationery) (5) He teaches man what he does not know." This surah is the first revelation revealed to the Prophet Muhammad. This revelation not only signifies that the prophet as an apostle or messenger, but also as a student who was educated by God and became an educator for all humanity. So, this revelation contains the core theory of learning design.

Thus, the basic concept and design of rabbani education learning process has several implications that can be actualized in the context of Islamic education in this era: first, rabbani education empties and ends at the peak of a life mission which is divinity or monotheism. Second, the rabbani education which has been through by the Prophet Muhammad is a reflection of the ideality of an Islamic education process. The concept and application of Islamic education must refer to what was done by the Prophet

${ }^{30}$ Ainul Yakin is a level of knowledge that knows God in addition to knowledge also through the senses. Abdul Munir Mulkhan, Nalar Spiritual Pendidikan..., h. 353. 
Muhammad. The process of education of the prophet does not tend to one particular ideology and learning theory. Thus, rabbani education reflected in the education of the prophet does not depend on one ideology, whether conservative, liberal or critical. Rabbani education does not tend to be behavioristic, cognitive, constructivistic, sociocultural (co-constructiveistic), humanistic, multiple intelligence, or other learning theories. Rabbani education is like the "light" that radiates to the whole concept of education.

\section{References}

Abdussalam, Abu. Konsep Pendidikan Rabbaniyah, Artikel Majelis Penulis.

Aizid, Rizem. Aktivasi Ilmu Laduni, Jogjakarta: Diva Pers, 2013.

Al-Hilali, Majdi. Menjadi Hamba Rabbani, Artikel Halaqah Keluarga 2012.

Arifi, Ahmad. Politik Pendidikan Islam: Menelusuri Ideologi Dan Aktualisasi Pendidikan Islam Di Tengah Arus Globalisasi. Yogyakarta: Teras, 2010

Enha, Ilung S. Laduni Quotient: Model Kecerdasan Masa Depan, Yogyakarta: Kaukaba Dipantara, 2013.

Enha, Ilung S. LQ: Eleven Pillars of Intelligence, Yogyakarta: Kaukaba Dipantara, 2013.

Fadil, SJ., Pasang Surut Peradaban Islam dalam Lintas Sejarah, Malang: UIN Malang Press, 2008

Fu'adi, Imam. Sejarah Peradaban Islam, Yogyakarta, Teras, 2011.

Ismail, Faisal. Paradigma Kebudayaan Islam: Studi Kritis dan Refleksi Historis, Yogyakarta: Titian Ilahi Press, 1998.

Kurniawan, Syamsul dan Erwin Mahrus, Jejak Pemikiran Tokoh Pendidikan Islam, Yogyakarta: Ar-Ruzz Media, 2011.

Mulkhan, Abdul Munir. Nalar Spiritual Pendidikan: Solusi Problem Filosofis Pendidikan Islam, Yogyakarta: PT Tiara Wacana Yogya, 2002..

Rahmat, Jalaluddin. Islam Alternatif Ceramah-ceramah di Kampus, Bandung: Mizan, 1986.

Saefuddin, AM. Desekularisasi Pemikiran Landasan Islamisasi, Bandung: Mizan, 1987.

Sekretaris Negara Republik Indonesia, Undang-Undang Republik Indonesia No. 20 Tahun 2003 Tentang Sistem Pendidikan Nasional (Sisdiknas), Bandung: Citra Umbara, 2010. 
Sunanto, Musyrifah. Sejarah Islam Klasik Perkembangan Ilmu Pengetahuan Islam, Jakarta: Prenada Media, 2004.

Syukri, Masitha Achmad. Urgensi Generasi Rabbani, Artikel dalam Majalah alHaromain, 2013.

Tasmara, Toto. Kecerdasan Ruhaniah (Transcedental Intelligence): Membentuk Kperibadian yang Bertanggung Jawab, Profesional, dan Berakhlak, Jakarta: Gema Insani Press, 2001.

Tobroni, Pendidikan Islam: Paradigma Teologis, Filosofis, dan Spiritualitas, Malang: UMM Press, 2008.

Yatim, Badri. Sejarah Peradaban Islam, Jakarta: PT RajaGrafindo Persada, 2011. 